\title{
Factors influencing the value added tax compliance in small and medium enterprises in
} Jordan

\author{
Amer Saadi Kallel Shakkour ${ }^{\mathrm{a}}$, Ahmad Ali Almohtaseb ${ }^{\mathbf{a}^{*}}$, Reem Khaled Matahen ${ }^{\mathrm{b}}$ and Naser Amer \\ Saadi Sahkkour ${ }^{\mathrm{c}}$
}

${ }^{a}$ Accounting and Finance Department, Al Hussein Bin Talal University, Maan, Jordan

${ }^{\mathrm{b}}$ Business Department, Al Hussein Bin Talal University, Maan, Jordan

${ }^{c}$ Administrative Sciences Department, Iman Abdulrahman Bin Faisal University, Dammam, Saudi Arabia

\section{H R O N I C L E}

\section{Article history:}

Received: July 10, 2020

Received in revised format:

October 182020

Accepted: November 6, 2020

Available online:

November 6, 2020

Keywords:

Value Added Tax

Jordan

Economic development

TX Compliance

Ability to Pay

Behavior Decision-Making

\section{A B S T R A C T}

This study aims to obtain the results of value added tax (VAT) compliance through behavioral decision theory with work personal attributes of the taxpayer's, tax understanding and taxpayer education, and ability to pay theory with tax compliance cost and audit system as a connecting variable to VAT compliance. The researcher randomly selected sample of $n=172$ small and medium enterprise owners from Jordan by using web-based survey questionnaires. Data analysis uses the SPSS 23.0 and validates the relationship between study variables. The researchers also propose a research model support by the behavior decision theory and the ability to pay approach. Findings reveal a strong positive relationship between personal characteristics, VAT education and tax compliance under both theoretical grounds and also indicate a positive correlation between VAT compliance cost, audit system and VAT compliance in Jordan. Addressing the understudies, this study extends the role of value added tax practices in SMEs. It provides some useful information to the government and policy makers to develop and impose the value added tax law on SMEs Level. Therefore, the researcher suggests more studies to investigate the factors affecting VAT compliance in Jordan by using the proposed conceptual model under consideration.

\section{Introduction}

Public Services are responsible for covering everything, including the health system, social security, welfare, education, infrastructure development and others. To manage these functions, the government obligates the citizen to pay taxes as with the collective action, public interest and development are possible (MFO, 2016). These taxes are directly associated with economic growth and development. For this purpose, local authorities establish an organized tax system that is a collection of tax administration, tax laws and tax administration. Establishing a tax system guarantees the successful implementation of fiscal policies and the public sector management system (Arifah \& Saidin, 2016). As noted by Zeqiraj and Nimani (2015), by collecting taxes, the state manages its tasks, which are focused on public well-being. Initially, governments used to collect taxes only from the narrow group of citizens; however, with time, categories, types and amounts of taxes kept on changing and expanding. For this purpose, the tax system introduced several fundamental principles that ensure the designated level of revenue depending on the specific economic and fiscal policies of the current state (OECD, 2015; Salloum, Al-Emran, et al., 2019). For this purpose, tax compliance is of greater importance that can maintain strong public finance as it is a process of managing public expenditures through equal distribution among the masses. To sustain tax compliance, policymakers, researchers and stakeholders also suggest adopting effective tax policies (Youde et al., 2019). In this regard, tax enforcement,

* Corresponding author.

E-mail address: muhtasebma@yahoo.com (A.A. Almohtaseb) 
in particular concerning the corporate sector, enhances corporate growth and formalization of business enterprises. Especially Modest Tax rates are essential for the medium and small level enterprise as the focus is widely towards economic growth and employment (World Bank, 2020). As a result, empirical data witnesses increased financial and audit rates and a reduction in tax rates. Those who understand the importance of tax, tax laws and perceived outcomes comparatively prefer more to compliance tax than the others (Nguyễn, 2013). Especially when the government offers additional fruitful products, people show increased compliance resulting in lower tax rates in the future (Alm et al., 1992). Here McGee and Yoon (2014) cited an example of fewer unemployment rates in South Korea due to tax compliance. As the researchers found a strong significant relationship between tax compliance and improved economy, they also witnessed opposing tax evasion among all the age groups, gender and occupations. According to Alm (2019), the state makes every possible effort to reinforce compliance behavior among taxpayers. Authorities offer special advisory services, deduction packages and also help people to pay in instalments. Just like personal income taxes, Value Added Tax is another primary form of taxation that also influence economic growth and development. Newly produced goods and services all contain Value Added Taxes that depend on the aggregate output (Ruebling, 1973). With its distinct features such as self-regulation, high efficiency and transparency, Value Added Tax is one of the primary building blocks of economic development and progress (Erfani et al., 2013). By keeping in view, the importance of Value Added Tax, back in January 2018, the United Arab Emirates, along with the Kingdom of Saudi Arabia, introduced the Value Added Tax system, and all the GCC countries agreed to implement a new taxation system. The newly introduced VAT system was designed, signed and executed by mutual agreement and support. Notably, in Jordan, Value Added Tax is applied with a 16\% rate on imported goods or services from outside Jordan and sales of services or goods. However, products, i.e. waters, bread and others packed in less than 5 litres, are exempted from tax. Services such as air transport, activities of public health, religious organizations, social activities and education are also exempted (PWC, 2020). Thus the implementation of taxation laws in Jordan witnessed several economic improvements, leading to decreased unemployment and increased public welfare (Fenochietto \& Ménard, 2016). Jordan also facilitated Value Added Tax paying by simplifying tax form and also introducing an online tax payment system (Profile, 2020). Table 1 below describes the necessary taxes included VAT, that is directly/ indirectly linked with the business enterprise in Jordan:

Table 1

Types of Business Related Taxes in Jordan:

\begin{tabular}{|c|c|c|c|c|c|c|c|}
\hline $\begin{array}{c}\text { Mandatory } \\
\text { Contribution or } \\
\text { Tax } \\
\end{array}$ & Payments & $\begin{array}{l}\text { Notes on } \\
\text { Payments }\end{array}$ & Time & $\begin{array}{l}\text { Statutory } \\
\text { Tax Rate }\end{array}$ & Tax base & $\begin{array}{c}\text { Total tax and } \\
\text { contribution } \\
\text { rate } \\
\end{array}$ & $\begin{array}{l}\text { Notes on } \\
\text { TTCR }\end{array}$ \\
\hline $\begin{array}{c}\text { Corporate Income } \\
\text { Tax }\end{array}$ & 1.0 & online & 8.5 & $14 \%$ & Taxable income & 10.48 & - \\
\hline Property tax & 1.0 & $\begin{array}{l}\text { Online and } \\
\text { jointly }\end{array}$ & - & $7.5 \%$ & $\begin{array}{l}\text { gross salaries and any } \\
\text { amount paid as a fixed } \\
\text { monthly amount }\end{array}$ & 0.45 & - \\
\hline Tax on interest & 0.0 & Jointly & - & $5.0 \%$ & Interest income & 0.13 & $\begin{array}{l}\text { Included in } \\
\text { other taxes }\end{array}$ \\
\hline $\begin{array}{l}\text { Municipal business } \\
\operatorname{tax}\end{array}$ & 1.0 & - & - & - & Fixed fee (200 JOD) & 0.10 & - \\
\hline GST & 1.0 & Online & 42 & $16.0 \%$ & Value Added & 0.00 & Not included \\
\hline
\end{tabular}

Source: (Loureiro, 2016)

Similarly, when it is mainly about Value Added Taxes in Jordan, we can see a consistency in tax rates as the sales tax rate is a tax charged to purchasers based on certain services' and goods' purchase price. The benchmark we use for the sales tax rate refers to the highest rate. Incomes from the Sales Tax Rate are an essential source of benefits for the government of Jordan. As the government obligates domestic level companies to pay tax on all the income, still the local administration also exempted export tax for the small and medium enterprises. Out of 16\% Value Added Tax (VAT), 4\% of tax implies the agriculture sector, i.e. meat, fruit, dairy products and others (Guide, 2013). Fig. 1 below presents the rates of Value Added Taxes (VAT) by year in Jordan.

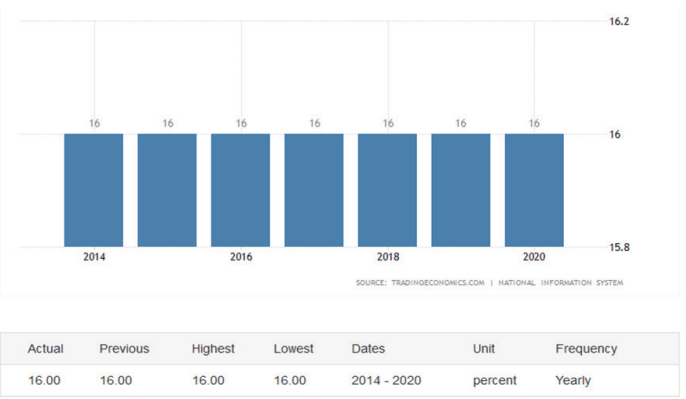

Fig. 1. the rates of Value Added Taxes (VAT) by year in Jordan Source: (Economics, 2020) 
However, still, many factors affect the Value Added Tax compliance in Jordan. For example, companies producing goods may not fulfil the designated sales goals, leading to tensions with local authorities. Financial issues can further raise operational challenges, employees' turnover, and pressures with legal authorities all can further harm the company's reputation (Deloitte, 2018). Similarly, tax compliance also depends on various social and psychological factors that determine compliance among taxpayers. Moreover, age, gender, educational level and others are also factors influencing tax compliance. Thus, these are both external and internal factors that further describe the tax compliance among the common man in general and enterprise owners in particular (Helhel \& Ahmed, 2014).

\section{Literature Review}

\subsection{Behavioral Decision Theory}

More than sixty years ago, Edward Wards proposed the Behavioral Decision-Making Theory (1954) in his seminal paper. Later, Behavioral Decision-Making theory started growing its roots also in business, organizational management, economics and other relevant fields. Although this Theory has both normative and descriptive domains, the normative domain is one of the most discussed and highlighted in contemporary scenarios (Habes et al., 2020; Keren, 1996). Regarding compliance; we assume that decision making largely depends on one's personal opinion and perceptions. To make a decision, people gather information, change their opinion accordingly, and take the appropriate step under their altered view. To elaborate on the decision-making process, Behavioral Decision Theory gives a robust conceptual foundation (Muhaisen et al., 2020; Redlawsk \& Lau, 2013). As many studies witness a strong significant influence of social and personal factors responsible for tax compliance among individuals. The perception regarding the importance of tax, the fairness of tax burden, tax compliance as an ethical responsibility, one's tax knowledge and others all are the factors that affect decision-making concerning tax compliance (Loureiro, 2016). Especially in small and medium enterprises, the owner's cognitive process determines tax compliance. They hire special tax advisors to keep check and balance on the tax audit and make decisions accordingly (Brown, 2016). Fig. 2 below gives an overview of the relationship between Taxpayer's attributes, tax education and VAT compliance under Behavioral Decision Theory.

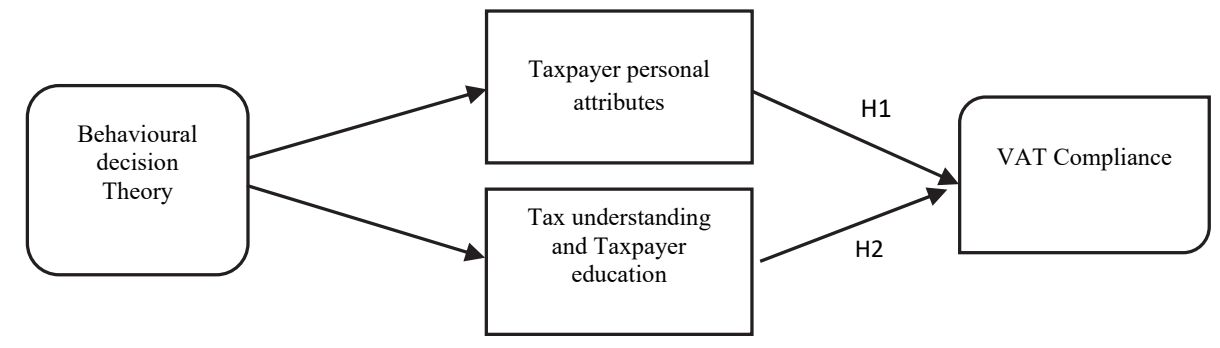

Fig. 2. Relationship between Taxpayer's Attributes, Tax Education and VAT Compliance Under Behavioral Decision Theory

\subsubsection{The relationship between Taxpayer's attributes and VAT Compliance}

People make decisions according to their logical and rational thinking. These decisions rely on perceived consequences, especially in the business organization, senior management and leadership make relevant decisions. Here decision-making approaches assume that decision-makers consider all the available choices and then switch to the most favorable ones (Aldag, 2012). Decision-making phenomenon can be understood under certain circumstances, i.e. certainty, under perceived importance, usefulness, positive outcomes and others. Similarly, demographical factors are also among the determinants of tax compliance behavior. For this purpose, the behavioral decision-making theory describes the decision as a result of personal attributes (Takemura \& Takemura, 2014). To further validate this phenomenon, (Marandu et al., 2015) highlighted the role of several factors, I.e. thinking, opinion, perceptions and others on tax compliance in general. The researchers selected a literature review approach and selected a sample of $n=18$ peer-reviewed research articles published from 1985 to 2012 . Findings showed that personal perceptions and opinions were the two basic determinants affecting tax compliance. Researchers concluded that people obligate laws when tax agents adopt a clients-friendly approach that further motivates them to comply with the tax rules. Similarly, (Eragbhe \& Aronmwan, 2015) investigated the role of personal attributes, i.e. age, gender, qualification and others regarding tax compliance in Nigeria. The researchers used a descriptive quantitative approach and selected a sample of local taxpayers. Results indicated that personal opinions and perceptions have a strong impact on tax compliance behavior. Similarly, the researcher also found age and gender as significantly influencing factors on the taxpayers' compliance decision. Further validated by Widianto (2015) as he scrutinized the impacts of demographical variables on the tax compliance in Indonesia. The researchers used the case study method and selected a sample of $n=2,383$ taxpayers from the Duren Sawit district. Results revealed that all the explanatory variables such as gender, age and education had a strong significant impact on tax compliance. Moreover, the income and size of the enterprise were moderately correlating with tax compliance behavior. As noted by (Hofmann et al., 2017), social and demographical variables strongly influence tax compliance behavior. To further validate this, the researchers conducted a meta-analysis of articles published from 1958 to 2012 in 111 countries worldwide. Results indicated a strong significant relationship age and tax compliance $(p=.012)$ gender $(p=.06)$, education $(p=.02)$ and income $(p=.04)$. However, researchers considered these results more consistent in developed countries than the 
developing ones. Likewise, (Fredrick \& Peter, 2019) examined tax compliance among sole proprietors and owners of medium and small size enterprises in Uganda. The researchers used a cross-sectional study approach and selected a sample of $n=284$ taxpayers through the Uganda Revenue Authority. Results showed that, among all the demographical variables, gender was the most prominent for having a direct and strong significant relationship with tax compliance. However, the relationship between age, education and tax compliance was moderately significant. One of the major factors influence VAT compliance is the personal attitude and perceptions of enterprise owners. These are the personal traits, attributes and dynamics of tax compliance (Akumbo et al., 2020). The researchers also investigated the correlation between personal attributes and tax compliance in Ghana. The researcher used descriptive quantitative approve and select a sample of $n=12$ individuals owning small and medium enterprise (administration $=25$, retail $=100$ and manufacturing $=75$ ). Results indicated people having an educational degree expressed comparatively higher compliance than the uneducated ones. According to the researchers, tax compliance increased when individuals consider tax compliance as important and ethical conduct. Thus by keeping in view the relationship between taxpayers' personal attributes, tax education and decision-making, the researcher the following hypothesis, supported by previously conducted studies:

\section{$\mathbf{H}_{1}$ : There is a positive relationship between personal attributes and VAT compliance in Jordan.}

\subsubsection{The relationship between Tax understanding, Tax Education and VAT Compliance}

According to Russell., (2010), countries can reinforce tax compliance by using effective strategies such as building robust tax collection laws, spreading tax education, adopting client-friendly approaches and using mass media resources to inform and educate the masses. For this purpose, there are many tax compliance strategies, among which knowledge enhancement is the most prominent one guarantying positive result. To make these straggles more effective, measuring tax knowledge-based surveys primarily help to determine the tax education level and the required programs for increasing tax compliance behavior (Ahmed, 2012; Al-Shibly et al., 2019). To validate the importance of tax education (Ndirangu, 2014) examined the impact of tax education on tax compliance behavior in Kenya. The researchers used the case study method and selected a sample of $n=$ 82 respondents from the motor vehicle spare parts industry in Nairobi. Results revealed that tax knowledge and tax education have a strong positive impact on tax compliance among motorcycle spare parts dealers. The researcher concluded that the government should take special steps to educate medium and small enterprise owners to obey tax law for positive tax compliance behavior. The revenue bodies need to employ the most effective approaches, such as educating the clients about the importance of tax. It is essential to understand the correlation between tax education and compliance behavior among the clients (Mascagni \& Santoro, 2016). Further validated by Torgler (2016) as the researcher examined different strategies to increase Value Added Tax compliance in Australia. The researcher used the case study method and gathered both primary and secondary data through field surveys and government records of taxpayers. Findings indicated policy briefs and tax education aimed at increasing tax knowledge play an influential role to increase tax compliance. Besides time pressure and strict conditions are two primary causes of tax non-compliance. In this regard, if the tax authorities adopt client friendly approaches and guide them accordingly, it will increase compliance behavior among the taxpayers. Gitaru (2017) also analyzed the impacts of tax education on tax compliance behavior in Kenya. The researcher used a cross-sectional study design and selected a sample of $n=100$ respondents having small and medium enterprises. Findings showed a positive, significant relationship between tax compliance and tax education among the taxpayers. However, the researcher also highlighted the importance of tax policies and tax agents' attitudes further to avail the favorable compliance decision from the clients. For instance, to decrease tax evasion, the local South African Tax Administration examined tax education among taxpayers. Results of nationwide surveys indicated that both small and large enterprises are suffering from a lack of tax education, leading to noncompliance behavior. However, those who were aware of the importance of tax as both ethical and social responsibility showed tax compliance as a part of their national duty (Mascagni \& Santoro, 2016).

Weak tax education adversely affects tax compliance among the taxpayers. Stakeholders and policymakers can design useful programs and strategies to educate taxpayers regarding the role of tax in economic development. Tax education and knowledge are the influential determinants of tax compliance, leading to positive social and economic outcomes (Mascagni et al., 2019). For this purpose, (Alhawamdeh et al., 2020; Oyedokun, 2019) highlighted influential sources of increased tax compliance in Nigeria. The researcher used a descriptive quantitative approach and selected a sample of $n=447$ small and medium enterprises in Lagos State. Results revealed personal education, special tax compliance training, newspapers and television as the most significant sources of increasing tax compliance behavior. Besides the special training programs, the researcher concluded mass media and interpersonal sources as highly effective in reinforcing tax compliance among enterprise owners. As noted by (Prichard et al., 2019), observers emphasize new strategies and ideas to educate the public for tax compliance brings fruitful outcomes. Many stories witnessed real success due to educating the potential taxpayers and persuading them as it purely based on optimistic results, particularly for the business owners.

\section{$\mathbf{H}_{2}$ : There is a positive relationship between tax education and VAT compliance in Jordan.}

\subsection{Ability to Pay Theory}

In Jordan, the corporate division is significant debate. However, tax compliance is highly visible. Many studies and theories show dividend policy as influential for the corporate industry (Nizar Al-Malkawi, 2007). In this regard, the Ability to pay 
Theory is one of the dominant theories, describing tax compliance in broader terms of sacrifice. This Theory describes tax compliance under three major interpretations: equal proportional, equal gift and comparable theories (Kendrick, 1939). As taxation equality is mainly "horizontal equity," implying those who are having the same economic position should pay an equal amount of tax. Similarly, in vertical equity, the tax should be charged based on individuals' income. For instance, vertical equity is progressively achieved by strategic policies and planning. Although tax rates discriminate on taxpayers' income, still a considerable level of tax compliance is recorded (Robert J. Vosslamber University, 2010). Similarly, today, the Ability to pay provides principles of fair taxation when it is about fiscal substance. Here, the concept demands tax fairness in which the tax burden is managed, and taxpaying is equally imposed on individuals (Podlipnik, 2017). Fig. 3 below gives an overview of the relationship between Tax compliance cost, audit system and Value Added Tax compliance in Jordan.

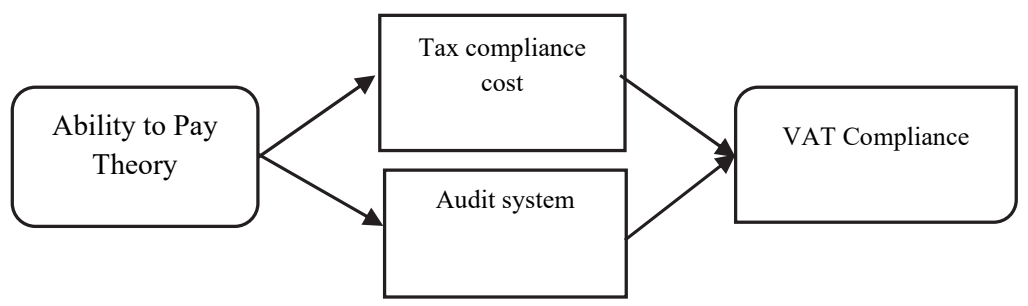

Fig. 3. Relationship between Tax Compliance Cost, Audit System, and Tax Compliance Under Ability to Pay Theory

\subsection{The relationship between tax compliance cost and VAT Compliance}

The simplification of the tax system and tax rates are important to avail tax compliance among the public. The main argument here emphasizes on appropriate development and implication of tax structure. Unequal tax rates and complexity in the tax system both can lead to tax evasion among the corporate level enterprise (Kopczuk, 2006). As an economic factor is one of the most prominent aspects is affecting tax compliance among small and medium compliance. When the tax burden is managed, policies are taxpayers' friendly and the aim is to facilitate the public, tax compliance is largely visible. However, the tax rate should be manageable and based on tax equity (Alm et al., 1992). To further affirm this, (Msangi, 2015) analyzed the Value Added Tax compliance under the Ability to pay and behavior decision theory in Tanzania. The researcher adopted case study approach and selected a sample of $\mathrm{n}=205$ local participants $(n=205$ taxpayers, $n=32$ tax agents). Findings revealed a positive relationship between tax rates and income of the companies indicating taxpayers' Ability to pay as the primary germinant of Value Added Tax compliance in Tanzania. The researcher empathized on tax equity and taxpayers' convenience to enhance compliance among people. (Wadesango et al., 2018) also investigated Value Added Tax compliance among small and medium enterprises in Zimbabwe. The researchers utilized the case study method and selected taxation records from the local tax department and administration. Findings revealed that economic considerations are among the most influential factors affecting VAT compliance in Zimbabwe. Taxpayers stay concerned about the tax rates and frequently record their taxrelated concerns to the local tax administration. Likewise, (Slemrod et al., 2019) further analyzed potential factors in Value Added Tax compliance among small and medium enterprises in Pakistan. The researchers used a descriptive quantitative method and selected $(n=100)$ workings for corporate sector organizations. Data revealed dichotomous findings as the researchers found the role of social factors, i.e. social pressure, peer pressure, media platforms and others as an essential factor affecting Value Added Tax compliance. Additionally, the size, income, sales and other economic factors were also among the significant factors affecting Value Added Tax compliance. Thus, the primary factors influencing Value Added Tax compliance are essential to study. Especially in those regions where economic development is a significant factor to upgrade a country both socially and economically. We argue that, besides personal behavior, tax compliance also depends on certain economic factors. The tax burden, tax equity, company's gross earning, sales and others all work as the basic mechanisms of Value Added Tax compliance (Pemstein, 2019). In this context, Fichtner et al. (2019) cited an example of the United States tax systems too costly to implement and relatively easy to evade the tax laws. The complicated tax system and simplistic evasion, today, a broader level tax deterrence is seen in the country. Apart from these two concerns, taxpayers are also facing higher tax rates, leading to tax evasion among the taxpayers. To counteract against existing tax evasion, (De Neve et al., 2019) conducted four experiments based on the stylized model of tax compliance modified under the model of criminal behavior by Becker (1968). Results indicated the three most prominent factors required more work to avail of tax compliance. These factors involved: Simplification of tax laws, (ii) Tax burden management and, (iii) the role of tax agents to educate and persuade the corporate sector.

$\boldsymbol{H}_{3}:$ There is a positive relationship between tax compliance cost and VAT compliance in Jordan.

\subsection{The relationship between Audit system and VAT Compliance}

Value Added Tax compliance plays a significant role in generating tax revenue for the country's economic development. The audit system works to ensure the accuracy of income declarations submitted by small and medium enterprise owners by undertaking Credit Control Exercise and Value Added Tax investigations. For this purpose, the audit system should counteract against potential defaulters, ensures that the audit department accurately determines Value Added Taxpayers' liability and 
evaluate the targets and outcomes to identify any weaknesses and alleviate them (National Audit Office, 2013). In this regard, (Modugu \& Anyaduba, 2014) investigated the impacts of the audit system and other qualitative characteristics of tax laws on tax compliance behavior in Nigeria. The researchers used the case study approach and selected a sample of $n=500$ questionnaires in five different geo-political zones. Results indicated a strong positive relationship between tax compliance and tax audit system. Similarly, tax evasion fines and penalties also found a widely obligating business sector for tax compliance in the country. Tax audit helps to improve tax compliance as it restricts the taxpayers for on-time payment. The progress of any country depends on the collect taxes and their investment in infrastructural development. Mostly Value Added Tax compliance plays a fundamental role, and the audit system makes every possible effort to collect tax from the nationwide business enterprise. In addition to raising revenue, the audit system helps to counteract non-compliance, applying suitable sanctions and publicizing the outcomes of audit activities (Mebratu, 2016). Further validated by Zandi and Elwahi (2016), as they scrutinized the role of the tax audit system regarding tax compliance behavior in Malaysia. These researchers used a mixed-method approach and gathered data by sing secondary records available from the Malaysian Inland Revenue Board (IRBM) and also by conducting field surveys from the respective tax audit department. Results indicated that despite the strict tax audit system, tax evasion is highly prevalent in Malaysia. The researchers concluded that to reinforce tax compliance, it is essential for their audit system to administrate their policies more strategically. To reinforce tax compliance behavior, tax authorities strive to transfer taxes to the government budget directly and to ensure tax control. Many times, tax collectors face difficulties while collecting taxes, especially Value Added Taxes from the small and medium enterprise. Some taxpayers do not pay their taxes, and some spend less than they should. This increased tax evasion raises several questions regarding the tax audit system and its compatibility. Therefore, increasing VAT compliance and decreasing VAT evasion is one of the essential national finance policies (Yildiz, 2019). Also affirmed by Olaoye and Ekundayo (2019), as they examined d the impacts of the audit system on tax compliance and remittance of Value Added Taxes revenue in Nigeria. The researchers used a cross-sectional study design and sleeted a sample of $n=60$ local tax audit staff members from Ekiti State. Results revealed ta strong significant relationship between back audit, desk audit, field audit, back audit, registration audit, remittance and tax compliance. However, field audit was the most significant predictor of tax compliance and remittance in the Ekiti State, Nigeria. Thus, to reinforce tax compliance, it is essential to scrutinize and question the compatibility of the local audit system. The knowledge about the strengths and weaknesses of the audit system can help to determine potential tax evasions and their reasons. To sustain the economy, tax compliance is essential; infrastructural development, public well-being, healthcare, education and all others are only possible if taxpayers comply with tax laws. In this regard, besides personal taxes, Value Added Tax compliance is equally essential (Alshrouf, 2019).

\section{H4: There is a positive relationship between audit system and VAT compliance in Jordan.}

\section{Conceptual Model}

According to Arindam., (2002), a conceptual framework describes the study path and the relationship under specific theoretical grounds. Here the purpose of the conceptual model is to organize the research process and avail generalizable results validated by relevant statistical analysis. Especially in empirical research, which is a thoughtful and systematic process, a conceptual framework provides strong functional guidance (Antonenko, 2014). Thus, the current study also involves a conceptual framework, proposed by under Ability to pay (Kendrick, 1939) and behavior decision theory (Keren, 1996). Fig. 4 below describes the conceptual model under factors affecting Value Added Tax compliance suggested by (KING'OINA, 2016). As noted by (Weber, 2007), behavior decision making relies on normative models, where one makes a relevant decision based on logical reasoning and socio-cultural perceptions. Similarly, the Ability of pay theory imposes tax compliance as responsibility for those who can pay. However, the role of the audit system is also of more significant concern in the Ability to pay perspective as the audit system need to be vigilant and taxpayers centred on facilitating the tax compliance process (Borthick \& Bowen, 2008).

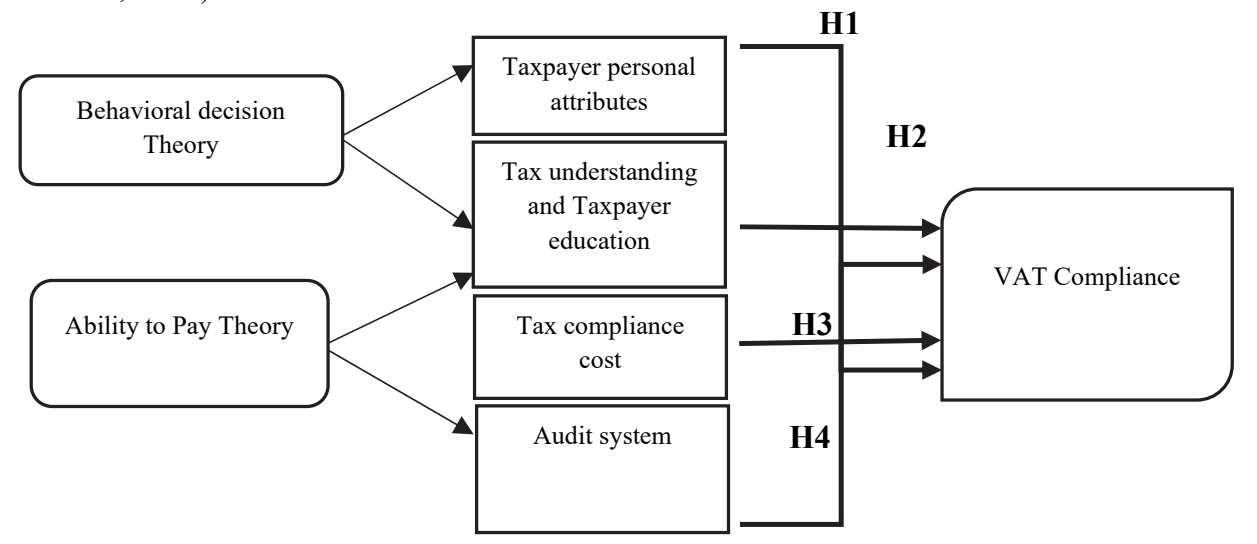

Fig. 4. The proposed study (KING'OINA, 2016) 


\section{Research Methodology}

\subsection{Research Design}

This study is exploratory and is based on Cross-sectional study design. As noted by Habes (2019), Hemed (2015), and Salloum Al-Emra et al. (2019) a cross-sectional study is based on availing direct outcomes from the group of population. These studies are snapshots of responses, providing generalizable results. To obtain data, the researchers further used close-ended, structured questionnaires as it is one of the most authenticated and commonly used scientific methods in research. Opinion research is of the most efficient research method giving generalizable results (Fincham \& Draugalis, 2013).

\subsection{Population \& Sampling}

The study population involves all the countrywide small and medium business enterprises working in Jordan. As the primary motive was to determine the factors influencing Value Added Tax compliance (Deloitte, 2018), the researcher specifically selected this population. Further, the researcher used a convenient sampling technique as this sampling technique involves selecting the respondents where they are conveniently available (Lavrakas, 2012). Thus, the researcher selected $n=172$ respondents from small and medium enterprises in Jordan by using web-based survey questionnaires.

\subsection{Demographical Data of the Participants}

Fig. 5 below gives a brief overview of the participants' demographical data, including their gender, age, qualification and firms size. As found, $63.7 \%$ of respondents were females, and $30.8 \%$ were males. Considering the age of respondents, $37.4 \%$ of respondents were aged between $26-30,19.8 \%$ of respondents ranged between $31-35,19.2$ participants were $36-40$, 11.6 ranged between $41-45,7 \%$ ranged between $26-35$ and $3.4 \%$ of respondents were 46 years old or above. Similarly, $40.6 \%$ of respondents had a graduation degree, $47.6 \%$ had Masters, and $11.6 \%$ of participants had Bachelors or below. Moreover, $62.0 \%$ of participants were small enterprise owners, and 33.0\% were medium enterprise owners. Therefore, the response rate was $100 \%$, as the participants filled all the questionnaires distributed among them.

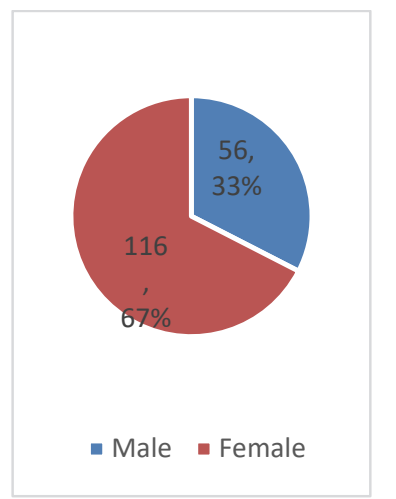

Gender

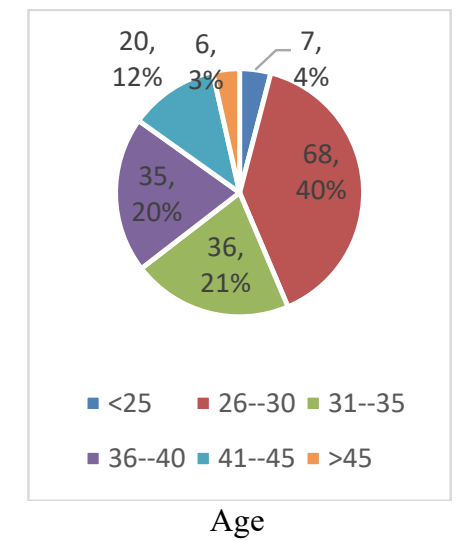

Age

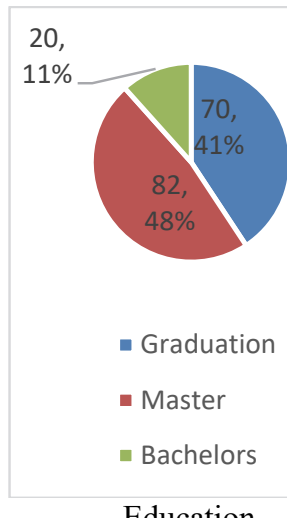

Education

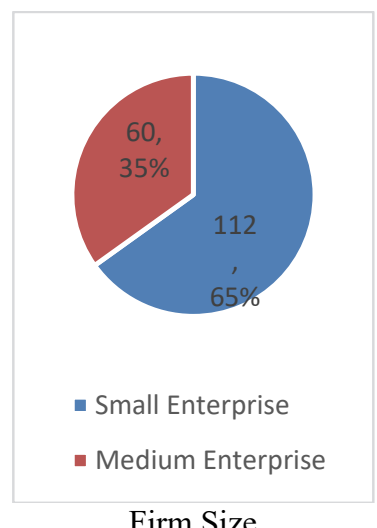

Firm Size

Fig. 5. Demographical Data of the Study Respondents

\subsection{Reliability Research Instrument}

According to Taherdoost (2018), reliability analysis is essential as it affirms the consistency in constructs and generalizability of the research outcomes. By keeping in view, the different levels assess the questionnaire to avail generalizable results, the current study also involves intercoder reliability analysis and with the overall Cronbach Alpha Value of $\alpha=.826$, we affirm that the research instrument is highly reliable. Table 2 below provides a detailed overview of Intercoder Reliability Analysis of research constructs.

Table 2

Intercoder Reliability Analysis

\begin{tabular}{ccc}
\hline Constructs & Cronbach Alpha Value & .751 \\
TAG & .723 & .784 \\
VATC & .812 \\
\hline
\end{tabular}

\section{Data Analysis \& Results}

The researcher used the Statistical Package for Social Science (SPSS) Version (23.0 64 bit) to perform data analysis as it is one of the most widely preferred software for data manipulation and analysis (Suresh, 2015). The assessment process took two phases as in the first phase, and the researcher analyzed the gathered responses (based on research instrument). In the second phase, the researcher tested the research hypotheses by using the linear regression technique. However, to examine 
any existing differences based on the respondents' characteristics and responses, the researcher also employed a One-way Analysis of Variance (ANOVA).

\subsection{Convergent Validity}

The researcher assed the measurement model by calculating construct reliability and validity, as also suggested by (Agarwal, 2013). Table 3 contains Cronbach Alpha Values ranging between .798 and .913. These values explicitly exceed the threshold value (.7) (Taber, 2018). Likewise, the composite reliability values range between .718 and .813 that also values exceed the threshold value (.7) (Peterson \& Kim, 2013). The table is given below also gives the values of AVE $([\boldsymbol{\lambda} \mathbf{i} 2] \mathbf{A V E}=\boldsymbol{\Sigma}[\boldsymbol{\lambda} \mathbf{i} 2 \mathbf{2}])$ and Hoteling's T-Squared. Therefore, we affirm the construct validity as all the value $+\boldsymbol{\Sigma}[\operatorname{Var}(\mathbf{\varepsilon i})]$ are sufficient, and we validate that the values of convergent validity are accepted.

\section{Table 3}

Convergent validity outcomes that assure acceptability of values (Factor loading, Cronbach's Alpha, reliability (composite), AVE $>0.5)$

\begin{tabular}{|c|c|c|c|c|c|}
\hline Constructs & Items & Cronbach Alpha & $\mathrm{CR}$ & Ave & Hoteling's T- \\
\hline \multirow{4}{*}{ Tax in General } & TAG1 & & & & \\
\hline & TAG2 & & & & \\
\hline & TAG3 & 0.798 & 0.718 & 0.612 & 0.000 \\
\hline & TAG4 & & & & \\
\hline \multirow{5}{*}{ Value Added Tax Compliance } & VATC1 & & & & \\
\hline & VATC2 & & & & \\
\hline & VATC3 & 0.802 & 0.716 & 0.0521 & 0.000 \\
\hline & VATC4 & & & & \\
\hline & VATC5 & & & & \\
\hline \multirow{5}{*}{ Tax Compliance Cost } & TCC1 & & & & \\
\hline & TCC2 & & & & \\
\hline & TCC3 & 0.792 & 0.717 & 0.557 & 0.000 \\
\hline & TCC4 & & & & \\
\hline & TCC5 & & & & \\
\hline \multirow{5}{*}{ Audit System } & AUS1 & & & & \\
\hline & AUS2 & & & & \\
\hline & AUS3 & 0.913 & 0.813 & 0.701 & 0.000 \\
\hline & AUS4 & & & & \\
\hline & AUS5 & & & & \\
\hline
\end{tabular}

\subsection{Discriminant Validity}

Discriminant validity is a potential method of capturing latent variables and is more concerned with the selection of variables (Zait et al., 2011). For this purpose, Fornel Larker Scale and Heterotrait-Monotrait Ratio (HTMT) are of greater significance (Engellant et al., 2016). Table 4 below contains the outputs of Forner Larker Scales as the results fulfill the criterion as the square root value of AVE exceeds the value of the correlation between other constructs and AVE (Fornell \& Lacker, 1981).

\subsubsection{Fornel Larker Scale}

\section{Table 4}

Fornel Larker Scale to Examine the Discriminant Validity

\begin{tabular}{ccccc}
\hline & TAG & VAT & TCC & \\
\hline TAG & 1.037 & & \\
VATC & .760 & 1.6038 & 1.961 \\
TCC & .283 & 1.00 & .250 & \\
AUS & .504 & .804 & 1.5481 \\
\hline
\end{tabular}

Note: TAF: Tax Compliance in General, VATC: Value Tax Compliance, TCC: Tax Compliance Cost, AUS: Audit System

\subsubsection{Heterotrait-Monotrait Ratio (HTMT)}

Table 6 below contains the values of the Heterotrait-Monotrait Ratio, which is less than 0.85 , which is lower than the threshold value. Thus, the Heterotrait-Monotrait Ratio also validates the discriminant validity. The results of HTMT affirm that the measurement model validates levels of validity and reliability. Indicating that it is feasible to utilize the data for assessing the relationship between proposed study variables.

\section{Table 5}

Heterotrait-Monotrait Ratio to Examine the Discriminant Validity

\begin{tabular}{cccc}
\hline & TAG & VAT & TCC \\
\hline TAG & .700 & & \\
VATC & .618 & .605 & -0.14 \\
TCC & -.371 & -0.14 & -.103 \\
AUS & .513 & .683 & .193 \\
\hline
\end{tabular}

Note: TAF: Tax Compliance in General, VAT: Value Tax Compliance, TCC: Tax Compliance Cost, AUS: Audit System 


\subsection{One-Way Analysis of Variance}

The researcher employed the One-way Analysis of Variance (ANOVA) to examine any existing differences among the group means (Sawyer, 2009). As given in Table 6 below, we found no significant difference between the participants' responses based on their demographical data. Therefore, we validate that the relationship between demographical data with Value Added Tax compliance is controlled.

Table 6

Homogeneity of Variances between the Group Means

\begin{tabular}{|c|c|c|c|c|c|c|c|}
\hline & & $\mathbf{N}$ & Mean & SD & Levene Statistics & $f$ & Sign \\
\hline \multirow{3}{*}{ Gender } & Male & 56 & .247 & .589 & \multirow{3}{*}{.422} & \multirow{3}{*}{.104} & \multirow{3}{*}{.737} \\
\hline & Female & 116 & .317 & 1.266 & & & \\
\hline & Count & 172 & - & - & & & \\
\hline \multirow{6}{*}{ Age } & 25 or below & 36 & 1.38 & .506 & \multirow{6}{*}{1.152} & \multirow{6}{*}{.267} & \multirow{6}{*}{$\begin{array}{c}.330 \\
.\end{array}$} \\
\hline & $26-30$ & 35 & 1.33 & .478 & & & \\
\hline & $31-35$ & 20 & 1.35 & .480 & & & \\
\hline & $36-40$ & 6 & 3.62 & 1.261 & & & \\
\hline & $41-45$ & 36 & 3.46 & 1.211 & & & \\
\hline & 36 or above & 35 & 3.50 & 1.213 & & & \\
\hline \multirow{4}{*}{ Qualification } & Bachelors & 20 & 2.54 & 1.266 & \multirow{4}{*}{.341} & \multirow{4}{*}{.464} & \multirow{4}{*}{.796} \\
\hline & Graduation & 6 & 2.72 & 1.099 & & & \\
\hline & Masters & 20 & 2.67 & 1.133 & & & \\
\hline & Small & 112 & 1.38 & .506 & & & \\
\hline Enterprise & Medium & 60 & 1.33 & .478 & .701 & .404 & .224 \\
\hline
\end{tabular}

\subsection{Factors Affecting VAT Compliance: Behavioral Decision Theory}

Descriptive data of responses gathered from participants' revealed that $51.1 \%$ of respondents strongly agreed that tax compliance is a more significant source of accelerating economic development (Chigbu \& Ali, 2014) and raising the living standard in general (51.1\%). For the 58.2\%, participants tax helps to alleviate unemployment and primarily facilitates social well-being (51.1\%). Similarly, regarding the role of Value Added Taxes, 51.1\% respondents strongly agreed that they support Value Added Taxes in general, and 65.4\% also obey Value Added Tax laws in Jordan as they (51.1\%) consider VAT compliance as their ethical responsibility (51.1\%) and prefer to pay (76.6\%) pay Value Added Taxes in the first place. These results are consistent with the (Mohd Rizal Palil, 2011) as they also found tax compliance due to personal factors, i.e. subjective opinion, tax education and others.

\section{Table 7}

Summary of Value Added Tax Compliance \& Behavior Decision Making

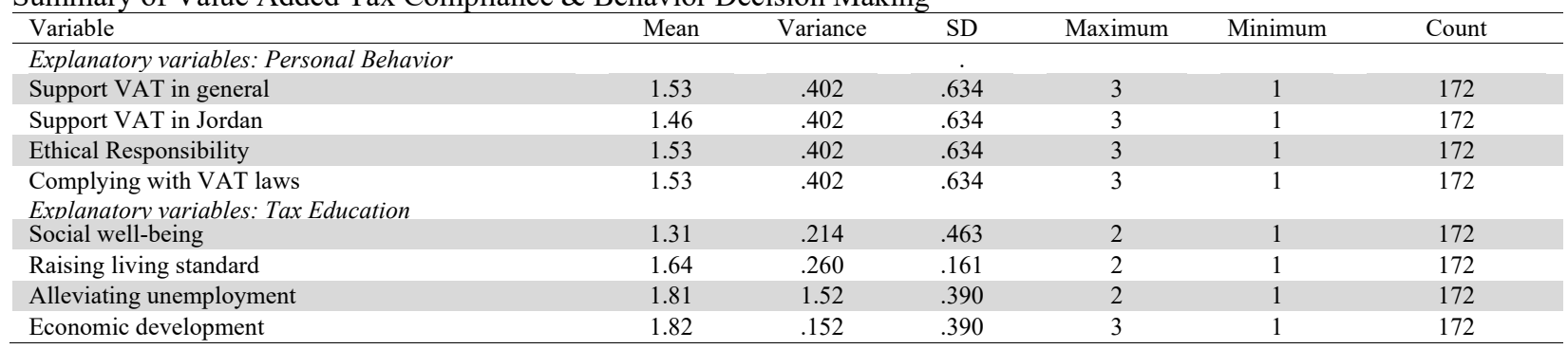

\subsection{Factors Affecting VAT Compliance: Ability to Pay Theory}

According to Arindam., (2002), tax compliance is widely seen when their negative effects are minimized on the taxpayers. To improve tax compliance factors such as tax compliance costs, lenient audit systems and others that aim to facilitate the taxpayers, the Ability to pay Theory gives special considerations (Nizar Al-Malkawi, 2007). In this regard, 63.3\% of respondents agreed that the Value Added Tax rates are too high in Jordan, and $(73,1 \%)$ they are not satisfied with tax rates. $65.9 \%$ of respondents also agreed that their income is not adequate to comply with Value-Added Taxes as local tax culture is unequal (73.1\%), and according to the size of their enterprise, current taxes are not appropriate for them (73.1\%). Likewise, considering the audit system in Jordan, $72.5 \%$ of respondents revealed that the audit system is not sufficient due to consistent alterations $(65.4 \%)$ in the overall tax system nationwide. As indicated by $65.4 \%$ of participants, continuous reforms are hindering the appropriate enforcement of tax laws, adversely affecting tax penalties for non-compliance behavior. Moreover, according to $79.7 \%$ of respondents, varying tax rates from organization to organization is another major weakness of the tax audit system, hindering economic progress. These results are compatible with the study conducted by (Pemstein, 2019) where the researcher describes tax compliance cost and audit system affecting compliance behavior in Zambia. 
Table 8

Summary of Value Added Tax Compliance \& Ability to Pay

\begin{tabular}{|c|c|c|c|c|c|c|}
\hline Variable & Mean & Variance & SD & Maximum & Minimum & Count \\
\hline \multicolumn{7}{|c|}{ Explanatory variables: Tax Compliance Cost } \\
\hline VAT rates in Jordan & 1.92 & .301 & .548 & 2 & 1 & 172 \\
\hline Unfair VAT in Jordan & 1.85 & .222 & .472 & 3 & 1 & 172 \\
\hline Unable to pay VAT & 1.92 & .282 & .240 & 3 & 1 & 172 \\
\hline Unequal taxpaying culture & 1.23 & .222 & .472 & 3 & 1 & 172 \\
\hline \multicolumn{7}{|c|}{ Explanatory variables: Audit System } \\
\hline Insufficient audit system & 1.38 & .180 & .472 & & & \\
\hline Reforming of tax laws in Jordan & 1.31 & .390 & .424 & 3 & 1 & 172 \\
\hline Tax penalties & 1.31 & .214 & .524 & 2 & 1 & 172 \\
\hline Varying compliance & 1.16 & .214 & .463 & 3 & 1 & 172 \\
\hline Hinder economic growth & 1.31 & .133 & .472 & 3 & 1 & 172 \\
\hline
\end{tabular}

\subsection{Hypotheses Testing}

To test the relationship between Personal Attributes, Value Added Tax Compliance, VAT Cost, Audit System and VAT Compliance in Jordan, the researcher utilized the Simple Linear Regression Technique. As noted by (Srivastava, 2019), Simple Linear Regression is a useful technique to examine the relationship between study variables. The formula of linear regression involves $y=\boldsymbol{\beta}_{0+} \boldsymbol{\beta}_{1} X+€$, where $X$ is the explanatory variable, $y$ is the dependent variable. Similarly, $\boldsymbol{\beta}_{0}$ and $\boldsymbol{\beta}_{1}$ are the parameters of the model where $\beta_{0}$ is the intercept term and $\beta_{1}$ is known as the slope parameter. These parameters are widely known as regression coefficients. Thus, in the current study, the regression analysis affirmed all the stated H1, H2, H3 and H4 hypotheses. We found a positive relation between Personal Attributes, Value Added Tax Compliance, VAT Cost, Audit System and VAT Compliance $(\beta=2.083, P=.0=21),(\beta=.962, P=.000),(\beta=2.314, P=.000)$ and $(\beta=.810, P=.000)$ respectively.

\section{Table 9}

Hypotheses-testing of the research model (significant at $p^{* *<}<.000, p^{*}<0.05$ ).

\begin{tabular}{|c|c|c|c|c|c|c|}
\hline Hypothesis & Relation & $f$ & $t$ & $p$ & Direction & Decision \\
\hline H1 & $\mathrm{DEM}>\mathrm{TAG}$ & 1.570 & 24.741 & .021 & Positive & Accepted \\
\hline H2 & $\mathrm{VAT}>\mathrm{TAG}$ & 10.54 & 13.778 & .000 & Positive & Accepted \\
\hline H3 & $\mathrm{TCC}>\mathrm{TAG}$ & 27.190 & 26.208 & .000 & Positive & Accepted \\
\hline H4 & AUS $>$ TAG & 60.630 & 12.466 & .000 & Positive & Accepted \\
\hline
\end{tabular}

Note: TAF: Tax Compliance in General, VAT: Value Tax Compliance, TCC: Tax Compliance Cost, AUS: Audit System

\section{Discussion}

According to Alshira'h et al., (2020), when we raise the question regarding the government's role in facilitating social wellbeing and improvement, researchers and stakeholders question the tax compliance ratio. Here tax revenue collection plays a significant part in issuing taxes and keeping their record. Similarly, to reduce tax evasion in the corporate sector, the government uses different tactics to reinforce compliance behavior among the masses (Slehat, 2009).

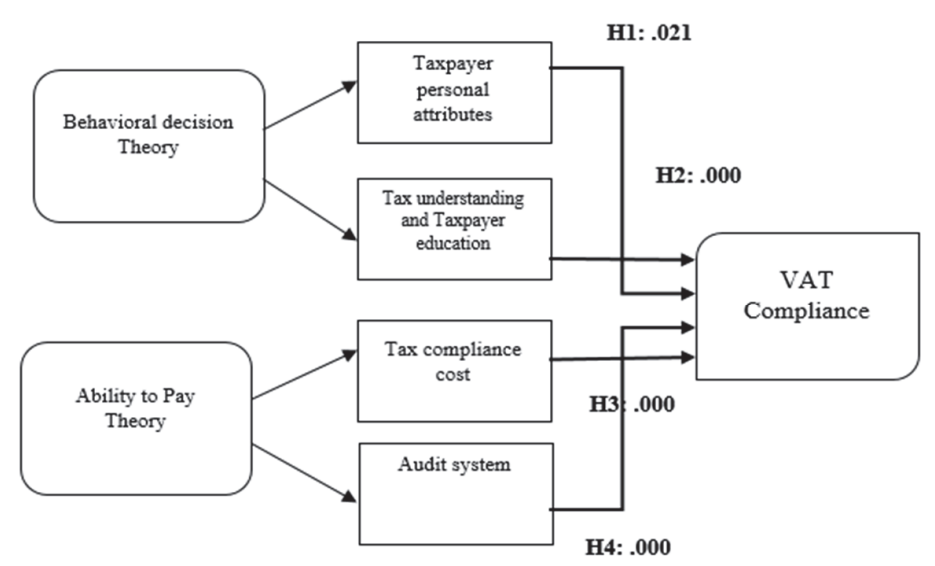

Many assume that small enterprise comparatively shows a higher Value Added Tax compliance than the older ones. However, we found this varying compliance is a result of several internal and external factors, depending on the size and type of the organization. These factors are highlight associated with the tax system and personal behavior, determining the compliance attitude among the taxpayers (Eragbhe \& Omoye, 2014). Similarly, economic models also highlight the improvement of the 
current financial system to avail compliance behavior. Results of previous studies also witnessed taxpayers perceive tax compliance as a key to lower penalties as they know about the sanctions of non-compliance, especially in Jordan (Webley et al., 2002; Alghizzawi et al., 2019). The principles and perceived outcomes of Value Added Tax compliance are almost the same everywhere; however, the rules, laws and rates can vary from region to region. Where besides the behavioural factors, other two previously discussed factors (audit system, tax compliance cost) are positively affecting, Value Added Tax compliance is highly visible (Symons et al., 2010). As noted by (Holcombe, 2010), countries across the world witness Value Added Tax compliance as a significant source of financing economic government, the current discussion about Value Added Tax is a long-running debate. Notably, in Jordan, several studies witnessed Value Added Tax non-compliance as a significant factor that can undermine the country's economic growth in future (Farhan et al., 2018). However, the current study highlighted some of these factors and the results are compatible with the study conducted by (Loureiro, 2016; Podlipnik, 2017) as they consider value Added Tax compliance as a result of one's personal behavior and costs attributed to local tax system in the country. We found a strong, positive correlation between behavioral aspects $(p \geq .000, p \geq 0.21)$ and other external aspects $(p$ $\geq .000, p \geq .000$ ), affecting the Value Added Tax compliance in the country. Still, to further reinforce Value Added Tax compliance in Jordan, (Dalton et al., 2019) suggest that the government should sign social treaties with the public, mentioning all the terms and tax compliance as a socially ethical responsibility. The public should also know the importance of tax as a source of fostering financial growth and raising the living standard. Likewise, the audit system also needs relevant reformations as the role of the audit system in the contemporary tax system extends beyond just collecting text (Zandi \& Elwahi, 2016). Additionally, tax compliance costs leading to voluntary compliance and reducing the fear of penalties are in line with the spirits of the tax audit system. As tax compliance happens when taxpayers obey laws and pay their taxes on time, tax compliance cost is a greater concern (Minovia, 2016). Thus, the current 16\% rate of business in Jordan was first implemented in 2008, and later, along-with categorization of business taxes (VAT, GST, Income and others), seven states signed the treaty of imposing a 16\% tax for economic progress and well-being (Jamil et al., 2011). Today in Jordan, the business community is playing a $99.0 \%$ role in improving the country's economy by paying various types of business taxes. $60 \%$ of the workforce is also associated with these small and medium enterprises countrywide. Similarly, the Association of Bank is also contributing to GDB by contributing 50\% of revenue annually (Alshira'h \& Abdul-Jabbar, 2019). Here the role of the Jordanian government is definitive and influential, so despite value Added Tax evasion in the country, they are making efforts to reinforce compliance among the owners of the small and medium enterprise (Alshirah et al., 2019).

\section{Conclusion}

The purpose of this study was to explore the role of behavioral decision theory and ability to pay theory on VAT compliance in SMEs sector in Jorden. The focus of this study was on those factors which are become the cause of positive effect of Vat compliance in SMEs. However, the study found the personal characteristics, VAT education, tax compliance, and audit system have positive effect on VAT compliance particularly within SMEs sector in Jorden. Moreover, the implications of these two theories was a unique source that influence the directly and indirectly to change the tax rules JOD100. In term of practical implications, the findings provided the improvement of to control the Tax evasion system. As well as, the positive effect of these two theories can help to policy makers and government to develop the alternative valued added tax laws and practices for small and medium enterprises (SMEs).

In Jordan, Value Added Tax is of greater significance, and noncompliance can hamper the state progress in general. To counteract against tax evasion in the country, criminal penalty of JOD200 plus output tax is imposed. Similarly, when a new business is established and shows non-compliance, a sentence of two to three times the product tax plus a criminal penalty equivalent to JOD200 is inflicted if the registration date is more than sixty days from the date on which the business has been registered. Likewise, a fine of JOD100 is imposed if the registration date is less than 60 days from the date the company has been registered. However, for a second offense, the criminal penalty imposed is doubled. If the violation occurs again within one year, the court may inflict the highest criminal fine or imprisonment for a period not less than months and not overdoing six months, or both. Therefore, Value Added Tax is one of the most significant reforms of the country's public finance s and requires strategic implementation and client's friendly policies to reinforce VAT compliance among them.

\section{Limitation and Recommendations}

This study involves two theories, applied one by one on the groups of different factors affecting Value Added Tax compliance in Jordan. To examine the proposed variables, the researcher also presented a study model and tested the relationship between them. The proposed model can be future used to assess the same topic in other countries with different methodologies and proportions under-designed research model. The primary study limitation involves using a convenient sampling technique, which consists of the researcher's bias. However, due to the current lockdown situation, during the Covid-19 outbreak, a convenient sampling technique was the only method to gather data from the respondents. Similarly, the proposed relationships could also be associated with other variables, which further limits the scope of the current study. Therefore, the researcher suggests more studies to examine the factors affecting Value Added Tax compliance in Jordan hampering the country's economic growth.

\section{References}

Agarwal, V. (2013). Investigating the convergent validity of organizational trust. Journal of Communication Management, 17(1), 
24-39. https://doi.org/10.1108/13632541311300133

Ahmed, N. (2012). Improving Tax Compliance in Developing Economies : PLEASE DO NOT CITE OR CIRCULATE WITHOUT PERMISSION. December.

Akumbo, S., Mbilla, E., Abiire, M. A., Atindaana, P. A., Ayimpoya, R. N., \& Polytechnic, B. (2020). Tax Education And Tax Compliance In Ghana. 8(1), 1-22.

Al-Shibly, M. S., Alghizzawi, M., Habes, M., \& Salloum, S. A. (2019). The Impact of De-marketing in Reducing Jordanian Youth Consumption of Energy Drinks. International Conference on Advanced Intelligent Systems and Informatics, 427-437.

Aldag, R. J. (2012). Distinguished Scholar Invited Essay Behavioral Decision Making. Journal of Leadership \& Organizational Studies, 19(2), 133-141. https://doi.org/10.1177/1548051812442745

Alghizzawi, M., Habes, M., Salloum, S. A., Ghani, M. A., Mhamdi, C., \& Shaalan, K. (2019). The effect of social media usage on students'e-learning acceptance in higher education: A case study from the United Arab Emirates. International Journal of Information Technology and Language Studies, 3(3).

Alhawamdeh, A. K., Alghizzaw, M., Habes, M., \& Alshibly, M. S. (2020). The Relationship Between Media Marketing Advertising and Encouraging Jordanian Women to Conduct Early Detection of Breast Cancer.

Alm, J. (2019). What Motivates Tax Compliance? Journal of Economic Surveys, 33(2), 353-388. https://doi.org/10.1111/joes.12272

Alm, J., McClelland, G. H., \& Schulze, W. D. (1992). Why do people pay taxes? Journal of Public Economics, 48(1), 21-38.

Alnawafleh, H., Alghizzawi, M., \& Habes, M. (2019). The impact of introducing international brands on the development of Jordanian tourism. International Journal of Information Technology and Language Studies, 3(2).

Alshira'h, A. F., \& Abdul-Jabbar, H. (2019). A Conceptual Model of Sales Tax Compliance among Jordanian SMEs and Its Implications for Future Research. International Journal of Economics and Finance, $11(5), 114$. https://doi.org/10.5539/ijef.v11n5p114

Alshira'h, A. F., AL-Shatnawi, H. M., Alsqour, M. K., \& Alshirah, M. H. (2020). The Influence of Tax Complexity on Sales Tax Compliance among Jordanian SMEs. International Journal of Academic Research in Accounting, Finance and Management Sciences, 10(1), 250-260. https://doi.org/10.6007/ijarafms/v10-i1/7172

Alshirah, A. F., Jabbar, H. A.-, \& Samsudin, R. S. (2019). The Effect of Tax Moral on Sales Tax Compliance among Jordanian SME. International Journal of Academic Research in Accounting, Finance and Management Sciences, 9(1), 30-41. https://doi.org/10.6007/ijarafms/v9-i1/5722

Alshrouf, M. (2019). The Effect of Tax Audit Using the Computer on Tax Non-Compliance in Palestine. International Journal of Academic Research in Business and Social Sciences, 9(3), 296-304. https://doi.org/10.6007/ijarbss/v9-i3/5678

Antonenko, P. D. (2014). The instrumental value of conceptual frameworks in educational technology research. Educational Technology Research and Development, 63(1), 53-71. https://doi.org/10.1007/s11423-014-9363-4

Arifah, N., \& Saidin. (2016). The Role of Tax on Economic Growth. International Journal of Accounting \& Business Management, 4(2), 242-250. https://doi.org/10.24924/ijabm/2016.11/v4.iss2/242.250

Arindam, D.-G. (2002). The Economic Theory of Tax Compliance with special Reference to Tax Compliance Costs The Economic Theory of Tax Compliance with special Reference to Tax Compliance Costs *. Chattopadhyay and Das-Gupta, December, 127.

Borthick, A. F., \& Bowen, P. L. (2008). Auditing System Development: Constructing the Meaning of "Systematic and Rational" in the Context of Legacy Code Migration for Vendor Incentives. Journal of Information Systems, $22(1), 1$. https://doi.org/10.2308/tnis.2008.22.1.1

Brown, B. (2016). Decision Making in Corporate Taxation. 2016, 2004-2019.

Chigbu, E. E., \& Ali, P. I. (2014). Econometric Analysis of the Impact of Value Added Tax on Economic Growth in Nigeria. European Journal of Business and Management Www.Iiste.Org ISSN, 6(18).

Dalton, A. G., Manning, L. A., Jamison, J. C., Sen, I. K., Karver, J. G., Castaneda Nunez, J. L., Guedes, L. P., \& Mujica Estevez, S. B. (2019). Behavioral Insights for Tax Compliance. 1-24.

De Neve, J.-E., Imbert, C., Spinnewijn, J., Tsankova, T., \& Luts, M. (2019). How to Improve Tax Compliance? Evidence from Population-Wide Experiments in Belgium. SSRN Electronic Journal. https://doi.org/10.2139/ssrn.3389405

Deloitte. (2018). VAT in Oman.

Economics, T. (2020). Jordan Sales Tax Rate - GST |2014-2020 Data | 2021-2022 Forecast $\mid$ Historical $\mid$ Chart.

Engellant, K. A., Holland, D. D., \& Piper, R. T. (2016). Assessing Convergent and Discriminant Validity of the Motivation Construct for the Technology Integration Education (TIE) Model. Journal of Higher Education Theory \& Practice, 16(1), 37-50.

Eragbhe, E., \& Aronmwan, E. J. (2015). Taxpayers Income, Tax Payers Attributes And Personal Income Tax Compliance. African Journal of Management Sciences, May, 95-111.

Eragbhe, E., \& Omoye, A. S. (2014). SME characteristics and value added tax compliance costs in Nigeria. Mediterranean Journal of Social Sciences, 5(20), 614-620. https://doi.org/10.5901/mjss.2014.v5n20p614

Erfani, H., Rahbari, S., Heydari, A., \& Shahhosseini, F. (2013). The Study of the Factors that Influence on the Performance of Value Added Tax System in Iran. Singaporean Journal of Business, Economics and Management Studies, 1(6), 1-8. https://doi.org/10.12816/0003764

Farhan, A., Abdul-jabbar, H., \& Samsudin, R. S. (2018). Sales tax compliance model for the Jordanian small and medium enterprises. Journal of Advanced Research in Social and Behavioural Sciences, 10(2), 115-130.

Fenochietto, R., \& Ménard, G. (2016). The Hashemite Kingdom of Jordan: Improving the Design of the General Sales Tax, Customs Duties, and Tax Incentives for Investments. 31.

Fichtner, J. J., Trinca, J., \& Gale, W. G. (2019). Tax Administration: Compliance, Complexity, and Capacity. April.

Fincham, J. E., \& Draugalis, J. R. (2013). The importance of survey research standards. American Journal of Pharmaceutical Education, 77(1). https://doi.org/10.5688/ajpe7714 
Fornell, \& Lacker. (1981). Discriminant Validity Assessment: Use of Fornell \& Larcker criterion versus HTMT Criterion Discriminant Validity Assessment : Use of Fornell \& Larcker criterion versus HTMT Criterion. Journal of Physics: Conference Series PAPER, 890, 6 .

Fredrick, W. W., \& Peter, O. I. (2019). The Influence of Demographic Factors on Tax Payercompliance in Uganda. International Journal of Academic Research in Business and Social Sciences, 9(9), 537-557. https://doi.org/10.6007/ijarbss/v9-i9/6328

Gitaru, K. (2017). The effect of taxpayer education on tax compliance in Kenya. Munich Personal RePEc Archive, 2(80344), 1223.

Guide, T. (2013). Bahrain Tax Guide 2013.

Habes, M. (2019). The influence of personal motivation on using social TV: A Uses and Gratifications Approach. International Journal of Information Technology and Language Studies, 3(1).

Habes, M., Alghizzawi, M., Ali, S., SalihAlnaser, A., \& Salloum, S. A. (2020). The Relation among Marketing ads, via Digital Media and mitigate (COVID-19) pandemic in Jordan. International Journal of Advanced Scienc, 29(7), 2326-12348.

Helhel, Y. \&, \& Ahmed, Y. (2014). Factors Affecting Tax Attitudes and Tax Compliance : A Survey Study in Yemen. European Journal of Business and Management Online ), 6(22), 2222-2839.

Hemed, M. (2015). Training Course in Sexual and Reprodcutive Health Research-Cross-sectional studies. 12.

Hofmann, E., Voracek, M., Bock, C., \& Kirchler, E. (2017). Tax compliance across sociodemographic categories: Meta-analyses of survey studies in 111 countries. Journal of Economic Psychology, 62, 63-71. https://doi.org/10.1016/j.joep.2017.06.005

Holcombe, R. G. (2010). working paper The Value Added Tax: Too Costly for the United States The Value Added Tax: Too Costly for the United States. 10.

Jamil, F., Sufy, A., \& Jordan, A.-. (2011). The Oretical and Analytical Study of Tax law in Jordan according to the Two Laws: Income Tax and General Sales Tax, and Making Comparison between Tax incomings from 2004 till 2009. 1(5), $265-276$.

Kendrick, M. S. (1939). The Ability-to-Pay Theory of Taxation on JSTOR. The American Economic Review, 29(1).

Keren, G. (1996). Perspectives of behavioral decision making: Some critical notes. Organizational Behavior and Human Decision Processes, 65(3), 169-178. https://doi.org/10.1006/obhd.1996.0016

KING'OINA, J. O. (2016). Factors Influencing Value Added Tax Compliance Among the Construction Firms in Kisumu County, Kenya. November, 1-62.

Kopczuk, W. (2006). Tax simplification and tax compliance: An economic perspective. .... Addressing the Crisis in Tax Administration, Economic ..., 1-23.

Lavrakas, P. (2012). Encyclopedia of Survey Research Methods. In Encyclopedia of Survey Research Methods. Sage Publications, Inc. https://doi.org/10.4135/9781412963947

Loureiro, J. (2016). The role of identifiability, geographical distance and social norms on tax compliance: an experimental study. In Universidade do Porto (Issue September).

Suresh, M. (2015). Important of SPSS for Social Sciences Research. SSRN Electronic Journal. https://doi.org/10.2139/ssrn.2663283

Marandu, E. E., Mbekomize, C. J., \& Ifezue, A. N. (2015). Determinants of Tax Compliance: A Review of Factors and Conceptualizations. International Journal of Economics and Finance, 7(9). https://doi.org/10.5539/ijef.v7n9p207

Mascagni, G., \& Santoro, F. (2016). What is the Role of Taxpayer Education in Africa? (Issue April).

Mascagni, G., Santoro, F., \& Mukama, D. (2019). Teach to Comply? Evidence from a Taxpayer Education Programme in Rwanda (Issue February).

McGee, R. W., \& Yoon, Y. (2014). Attitudes Toward Tax Evasion in Korea: A Study in Public Finance. In Handbook of Asian Finance: Financial Markets and Sovereign Wealth Funds (Vol. 1, pp. 272-283). Elsevier Inc. https://doi.org/10.1016/B978-012-800982-6.00015-9

Mebratu, A. A. (2016). Impact of Tax Audit on Improving Taxpayers Compliance : Emperical Evidence from Ethiopian Revenue Authority at Federal Level. International Journal of Accounting Research, 2(12), 1-19. https://doi.org/10.12816/0033279

MFO. (2016). Significance and Role of Tax.

Minovia. (2016). The Impact of Tax Knowledge on Tax Compliance. Journal of Advanced Research in Business and Management Studies, 2(1), 22-30.

Modugu, K. P., \& Anyaduba, J. O. (2014). Impact of tax audit on tax compliance in Nigeria. International Journal of Business and Social Science, 5(9), 207-215.

Mohd Rizal Palil. (2011). Factors affecting tax compliance behaviour in self assessment system. African Journal of Business Management, 5(33). https://doi.org/10.5897/ajbm11.1742

Msangi, S. Y. (2015). Evaluation and Analysis of Value Added Tax (VAT) compliance: A Case Study of Small and Medium Enterprises in Tanzania. UNIVERSITY OF SOUTHAMPTON.

Muhaisen, O. Al, Habes, M., \& Alghizzawi, M. (2020). An Empirical Investigation the Use of Information, Communication Technologies to English Language Acquisition : A Case Study from the Jordan,. International Journal of Innovations in Engineering and Science, 7(5), 261-269.

Mureşan, M., David, D., Elek, L., \& Dumiter, F. (2014). Value added tax impact on economic activity: Importance, implication and assessment - The Romanian experience. Transylvanian Review of Administrative Sciences, 2014(December), 131-151.

National Audit Office, M. (2013). Performance Audit Reviewing VAT Liability: VAT Investigations and Credit Control Exercises.

Ndirangu, M. N. (2014). the University of Nairobi October 2014 Declaration. October.

Nguyễn, T.T. (2013). A Review of Factors impacting Tax Compliance. Australian Journal of Basic and Applied Sciences, 7(7), 476479.

Nizar Al-Malkawi, H. (2007). Determinants of Corporate Dividend Policy in Jordan: An Application of the Tobit Model. Journal of Economic and Administrative Sciences, 23(2), 44-70. https://doi.org/10.1108/10264116200700007

OECD. (2015). Fundamental principles of taxation. In Addressing the Tax Challenges of the Digital Economy (pp. 29-51). https://doi.org/10.1787/9789264237858-zh 
Olaoye, C. O., \& Ekundayo, A. T. (2019). Effects of Tax Audit on Tax Compliance and Remittance of Tax Revenue in Ekiti State. Open Journal of Accounting, 08(01), 1-17. https://doi.org/10.4236/ojacct.2019.81001

Oyedokun, G. E. (2019). Ae-Funai Journal of Accounting Business and Finance ( Fjabaf ). -, January.

Pemstein, D. (2019). The social dimensions of tax compliance. June.

Peterson, R. A., \& Kim, Y. (2013). On the relationship between coefficient alpha and composite reliability. Journal of Applied Psychology, 98(1), 194-198. https://doi.org/10.1037/a0030767

Poddar, S. (2003). Consumption Taxes: The Role of the Value-Added Tax. Taxation of Financial Intermediation: Theory and Practices for Emerging Economies, Section 2, 345-380.

Podlipnik, J. (2017). The Ability-to-Pay Principle as a Primarily Constitutional Basis for Tax Norms of a Financial Nature * Boštjan Koritnik ** \& Jernej Podlipnik***. June, 1-15.

Prichard, W., Custers, A., Dom, R., Davenport, S., \& Roscitt, M. (2019). Innovations in Tax Compliance: Conceptual Framework. October. https://doi.org/10.1596/1813-9450-9032

Profile, E. (2020). Jordan.

PWC. (2020). Jordan - Corporate - Other taxes.

Redlawsk, D. P., \& Lau, R. R. (2013). Behavioral Decision-Making. Oxford University Press. https://doi.org/10.1093/oxfordhb/9780199760107.013.0005

Robert J. Vosslamber University. (2010). TAXING AND PLEASING: THE RHETORIC AND REALITY OF VERTICAL EQUITY IN THE DEVELOPMENT OF THE NEW ZEALAND INCOME TAX ON EMPLOYEES, 1891 TO 1984 [University of Canterbury]. https://doi.org/10.1558/jsrnc.v4i1.24

Ruebling, C. E. (1973). A Value Added Tax and Factors Affecting Its Economic Impact. Review, 55, 15-19. https://doi.org/10.20955/r.55.15-19.xnr

Russell, B. (2010). Revenue Administration: Developing a Taxpayer Compliance Program. Technical Notes and Manuals. https://doi.org/10.5089/9781462314218.005

Salloum, S. A., Al-Emra, M., Habes, Mo., \& Alghizzawi, M. (2019). Understanding the Impact of Social Media Practices on ELearning Systems Acceptance. https://doi.org/10.1007/978-3-030-31129-2

Salloum, S. A., Al-Emran, M., Khalaf, R., Habes, M., \& Shaalan, K. (2019). An Innovative Study of E-Payment Systems Adoption in Higher Education: Theoretical Constructs and Empirical Analysis. International Journal of Interactive Mobile Technologies, 13(6).

Sawyer, S. F. (2009). Analysis of Variance: The Fundamental Concepts. Journal of Manual \& Manipulative Therapy, 17(2), 27E38E. https://doi.org/10.1179/jmt.2009.17.2.27e

Slehat, Y. A. A. A. (2009). The tendency toward tax evasion in Jordan. (Unpublished thesis master), Universiti Utara Malaysia.

Slemrod, J., Ur, O., \& Waseem, R. M. (2019). Nber Working Paper Series Pecuniary and Non-Pecuniary Motivations for Tax Compliance: Evidence From Pakistan.

Srivastava, V. K. (2019). Chapter 2 Simple Linear Regression Analysis. Regression Analysis, 1-42.

Symons, S., Howlett, N., \& Alcantara, K. R. (2010). The impact of VAT compliance on business. The World Bank/International Finance Corporation; Price Water House Coopers, 25543(09/10), 1-15.

Taber, K. S. (2018). The Use of Cronbach's Alpha When Developing and Reporting Research Instruments in Science Education. Research in Science Education, 48(6), 1273-1296. https://doi.org/10.1007/s11165-016-9602-2

Taherdoost, H. (2018). Validity and Reliability of the Research Instrument; How to Test the Validation of a Questionnaire/Survey in a Research. SSRN Electronic Journal, January 2016. https://doi.org/10.2139/ssrn.3205040

Takemura, K., \& Takemura, K. (2014). Decision-Making Phenomenon and Behavioral Decision Theory. In Behavioral Decision Theory (pp. 3-13). Springer Japan. https://doi.org/10.1007/978-4-431-54580-4 1

Torgler, B. (2016). Tax Compliance and Data: What Is Available and What Is Needed. Australian Economic Review, 49(3), 352364. https://doi.org/10.1111/1467-8462.12158

Wadesango, N., Mutema, A., Mhaka, C., \& Wadesango, V. O. (2018). Tax Compliance of Small and Medium Enterprises through the Self-Assessment System: Issues and Challenges. Academy of Accounting and Financial Studies Journal.

Weber, E. (2007). Behavioral Decision Theory: Lessons / Themes of the Course.

Webley, P., Adams, C., \& Elffers, H. (2002). Value Added Tax Compliance in the United Kingdom. December 2002.

Widianto, R. (2015). The effect of demographic factors on individual tax compliance in Duren Sawit (East Jakarta, Indonesia). Economic, Master of(December), 67.

World Bank. (n.d.). Why it matters in Paying Taxes - Doing Business - World Bank Group.

Yildiz, B. (2019). A Theoretical Analysis on Tax Auditing-Tax Compliance Determinants and Bomb Crater Effect. March.

Youde, S., Lim, S., Penh, P., Avoidance, T., \& Evasion, T. (2019). Tax Compliance.

Zait, A., Alexandru, U., \& Cuza, I. (2011). Methods for Testing Discriminant Validity. Management \& Marketing, 9(2), $217-224$.

Zandi, G., \& Elwahi, A. S. M. (2016). Tax Compliance Audit: The Perspectives of Tax Auditors in Malaysia. Asian Development Policy Review, 4(4), 143-149. https://doi.org/10.18488/journal.107/2016.4.4/107.4.143.149

Zeqiraj, V., \& Nimani, A. (2015). Taxes and their Effects on Business Environment. Academic Journal of Interdisciplinary Studies, March 2015. https://doi.org/10.5901/mjss.2015.v4n1p91

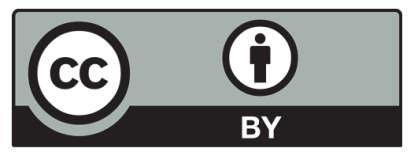

(C) 2021 by the authors; licensee Growing Science, Canada. This is an open access article distributed under the terms and conditions of the Creative Commons Attribution (CC-BY) license (http://creativecommons.org/licenses/by/4.0/). 